\title{
ОЦЕНКА СОВРЕМЕННОГО СОСТОЯНИЯ МОЛОЧНОГО СКОТОВОДСТВА В КОСТРОМСКОЙ ОБЛАСТИ
}

\author{
Е.Г. Федосенко (фото) \\ К.С.-Х.Н., заместитель директора по научной работе \\ Д.Г. Гвазава \\ Д.э.Н., К.С.-Х.Н., директор
}

ФГБНУ «Костромской научно-исследовательский институт сельского хозяйства», с. Минское

Уровень развития отрасли молочного скотоводства является одним из важнейших показателей развития сельского хозяйства, который позволяет судить об эффективности сельскохозяйственных

\section{Молочное скотоводство, современное состояние, продуктивность, кормовая база}

Dairy farming, current state, productivity, food supply предприятий, их инвестиционной привлекательности. Как и другие отрасли сельского хозяйства, молочное скотоводство должно быть рентабельным, конкурентоспособным и обеспечивать продовольственную независимость региона. В разных природно-экономических зонах развитие отрасли имеет свои особенности, это обусловлено структурой сельскохозяйственных угодий, направлением производства, почвенными и климатическими условиями $[1,2]$.

В связи с этим нами была поставлена цель - оценить состояние и перспективы развития молочного скотоводства в Костромской области.

\section{Методика}

Материалом для исследований послужили данные мониторинга показателей развития агропромышленного комплекса Костромской области, годовые отчёты о производстве продукции животноводства Департамента АПК Костромской области (форма № 13-АПК), результаты бонитировки крупного рогатого скота молочного направления продуктивности, данные ФГБУ ГСАС «Костромская» по качеству кормов. Для достижения поставленной цели были использованы статистико-экономический, расчётно-конструктивный и аналитический методы.

\section{Результаты исследований}

В настоящее время в молочном скотоводстве Костромской области наблюдается тенденция сокращения поголовья крупного рогатого скота, в том числе и коров, с одновременным ростом молочной продуктивности. Поголовье крупного рогатого скота молочного направления продуктивности в хозяйствах всех категорий по состоянию на 1 января 2019 года составило 37,6 тыс. голов (93,1\% к уровню прошлого года), в том числе коров 16,6 тыс. голов. 
По итогам за 2018 год среднегодовой надой молока на одну корову составил 5269 кг, что выше на 205 кг уровня 2017 года. Однако валовое производство молока в регионе за 2018 год в хозяйствах всех категорий осталось практически неизменным и составило 87,4 тыс. тонн [3].

Анализ показал, что объёмы производства молока и молочной продукции не удовлетворяют потребности населения Костромской области. В 2018 году потребление молока и молочных продуктов на душу населения региона составило лишь 231 кг, или 71\% от рекомендуемой нормы [4].

Подробный анализ современного состояния молочного скотоводства в Костромской области показал, что регион обладает достаточными внутренними резервами для повышения уровня производства молока и эффективности ведения отрасли в целом.

Проведённые исследования свидетельствуют, что практически все породы в регионе, кроме костромской, подверглись скрещиванию с голштинской. Полученные результаты говорят о положительном влиянии «голштинов» на повышение молочной продуктивности, скороспелости и способности к интенсивному раздою коров. Животные костромской породы обладают крепкой конституцией, отличаются высокой оплатой корма продукцией, устойчивы к заболеваниям лейкозом, туберкулёзом и бруцеллёзом, кроме того, характеризуются высокими удоями в течение длительного срока хозяйственного использования, легко адаптируются к интенсивным технологиям производства. Сложность сохранения породы состоит в том, что поголовье очень малочисленное, и из поколения в поколение нарастает степень инбридинга, что приводит к снижению жизнеспособности и продуктивности. В племенных хозяйствах по разведению костромской породы возникает сложность с закреплением быков-производителей к маточному поголовью. Нет семени быков костромских линий с высоким генетическим потенциалом продуктивности.

В молочном скотоводстве региона существует серьёзная проблема, связанная с воспроизводством стада: позднее осеменение коров (в возрасте 21 месяц) и длительный сервис-период (до 136 дней), особенно у высокопродуктивных животных. Чаще всего причиной этому становятся гинекологические заболевания коров и тёлок. Обусловлено это погрешностями в кормлении и нарушениями технологии содержания. В большей степени подвержены гинекологическим за- болеваниям коровы чёрно-пёстрой породы (68\% коров от общего числа выбывших животных), в меньшей - коровы костромской породы $(26,9 \%$ от общего числа выбывших животных).

Следствием длительного сервис-периода является низкий выход телят на 100 коров. В среднем этот показатель по Костромской области составляет 85 телят на 100 коров, в то время как здоровая корова при нормальных условиях содержания жизнедеятельности способна давать каждый год по телёнку.

Селекция на высокую продуктивность и внедрение промышленной технологии в молочном скотоводстве привели к значительному сокращению срока эксплуатации коров. Средняя продолжительность хозяйственного использования коров в Костромской области составляет всего 2,9 отёла. Таким образом, коровы не доживают до 4-5 лактации, когда проявляется наивысшая молочная продуктивность и окупаются затраты на выращивание тёлок и нетелей.

Анализ кормовой базы Костромской области показал, что качество заготавливаемых кормов не соответствует потребностям животноводства, а ежегодная потребность в комбикормах удовлетворяется лишь на $80 \%$. Обеспеченность животных другими видами кормов достаточно высокая, несмотря на значительный спад производства, что в большей степени связано с сокращением поголовья крупного рогатого скота. Доля неклассного сена в 2018 году составила 76\% от общего объёма производства, а доля силоса второго класса - $80 \%$, силоса первого класса вовсе не заготовлено. Корма не отвечают требованиям ГОСТ по содержанию клетчатки и сырого протеина. Низкое качество основных кормов вызывает необходимость балансирования рационов за счёт повышенного расхода концентратов, что экономически невыгодно.

Существенное влияние на молочную продуктивность коров оказывают технологии содержания, кормления и доения животных. 96\% поголовья молочных коров содержится на привязи, что характерно для молочного скотоводства, однако выпасается при этом только 55\% поголовья, что приводит к рождению слабых нежизнеспособных телят, снижению устойчивости скота к различным заболеваниям и срока хозяйственного использования. Для доения коров используются в основном стационарные доильные установки с транспортировкой молока по молокопроводу (83,4\% поголовья). В отдельных хозяйствах предусмотрены доильные залы типа Ёлочка, 
Параллель и Карусель, однако обслуживают они совсем небольшое поголовье коров - 4,7\%. Роботизированные доильные установки в Костромской области не применяются.

На наш взгляд, для увеличения объёмов производства молока и повышения продовольственной независимости региона, прежде всего, необходимо обеспечить рост поголовья крупного рогатого скота молочного и молочно-мясного направлений продуктивности. При этом желательно использовать современные методы, такие как интенсивное выращивание нетелей и тёлок, трансплантацию эмбрионов и др., позволяющие ускорить процесс воспроизводства. С целью поддержания биоразнообразия необходимо сохранение численности и дальнейшее совершенствование костромской породы крупного рогатого скота, которая является наиболее приспособленной к условиям Костромской области. Создание генофондных хозяйств по разведению скота костромской породы и накопление достаточного количества доз спермы от выдающихся производителей позволит решить эту проблему.

Наиболее эффективный способ увеличения объёмов производства продукции является интенсификация отрасли, то есть рост продуктивности скота на основе качественного улучшения стада за счёт совершенствования методов племенной работы. Более полно реализовать генетический потенциал существующих пород по молочной продуктивности позволит активное использование производителей, оцененных по качеству потомства как «улучшатель», выведение региональных и заводских типов, характеризующихся высокой продуктивностью и приспособленностью к местным условиям. Селекция на повышение массовой доли жира и белка в молоке разводимых пород обеспечит повышение цены реализации получаемой продукции и повышение рентабельности производства в целом.

Для повышения уровня селекционно-племенной работы в Костромской области необходимо восстановить племенную службу, которая позволит координировать и совершенствовать работу в данном направлении. Для каждого стада должна быть разработана программа селекции, которую следует неукоснительно выполнять с целью поддержания и повышения генетического потенциала животных. Причём разработанная программа должна быть согласована с программой селекции по региону и в целом по породе. Это позволит эффективно использовать имеющиеся генетические ресурсы [5].

Неотъемлемым условием повышения молочной продуктивности коров является полноценное и сбалансированное кормление и оптимальные условия кормления и содержания животных. Соблюдение технологий заготовки и сроков уборки трав, рациональное использование агроклиматических условий зоны и применение консервантов позволят получать корма высокого качества.

Внедрение в молочном скотоводстве Костромской области интенсивных технологий выращивания молодняка и тёлок, осеменение животных в более раннем возрасте позволит сократить непродуктивный период использования животных. Это в свою очередь снизит затраты сельскохозяйственных организаций на выращивание, повысит рентабельность производства молока и ускорит процесс воспроизводства.

\section{Выводы}

Таким образом, проведённые нами исследования показывают, что развитие молочного скотоводства в Костромской области возможно только при комплексном решении проблем технологического характера, совершенствовании селекционно-племенной работы, технологии заготовки и хранения кормов, а также при использовании современных методов профилактики и лечения животных. Что в свою очередь будет способствовать бесперебойному обеспечению населения молоком и молочными продуктами. И все эти меры должны осуществляться при активном участии учёных и специалистов.

\section{Лumepamypa}

1. Журавлева, М.Е. Резервы повышения эффективности молочного животноводства [Текст] / М.Е. Журавлева, Н.П. Сударев, Г.А. Шаркаева и др. // Молочное и мясное скотоводство. - 2015. - № 4. - С. 25-26.

2. Гвазава, Д.Г. Резервы повышения производства молока в Костромской области [Текст] / Д.Г. Гвазава, Е.Г. Федосенко // Вестник ИрГСХА. - 2018. - № 89. - С. 138-146.

3. Федеральная служба государственной статистики по Российской Федерации [Электронный ресурс]. - Режим доступа: http://www.gks.ru. 
4. Силаева, Л.П. Размещение производства и потребление молока в Российской Федерации [Текст] / Л.П. Силаева, С.А. Алексеев, А.П. Захарова // Вестник Курской государственной сельскохозяйственной академии. - 2017. - № 2. - С. 44-50.

5. Федосенко, Е.Г. Оценка племенной базы в молочном скотоводстве Костромской области [Текст] / Е.Г. Федосенко, Д.Г. Гвазава // Вестник АПК Верхневолжья. - 2018. - № 3 (43). - С. 46-49.

\section{References}

1.Zhuravleva,M.E. Rezervy povyshenijajeffektivnosti molochnogo zhivotnovodstva [Tekst]/M.E.Zhuravleva, N.P. Sudarev, G.A. Sharkaeva i dr. // Molochnoe i mjasnoe skotovodstvo. - 2015. - № 4. - S. 25-26.

2. Gvazava, D.G. Rezervy povyshenija proizvodstva moloka v Kostromskoj oblasti [Tekst] / D.G. Gvazava, E.G. Fedosenko // Vestnik IrGSHA. - 2018. - № 89. - S. 138-146.

3. Federal'naja sluzhba gosudarstvennoj statistiki po Rossijskoj Federacii [Jelektronnyj resurs]. - Rezhim dostupa: http://www.gks.ru.

4. Silaeva, L.P. Razmeshhenie proizvodstva i potreblenie moloka v Rossijskoj Federacii [Tekst] / L.P. Silaeva, S.A. Alekseev, A.P. Zakharova //Vestnik Kurskoj gosudarstvennoj sel'skohozjajstvennoj akademii. - 2017. - № 2. S. 44-50.

5. Fedosenko, E.G. Ocenka plemennoj bazy v molochnom skotovodstve Kostromskoj oblasti [Tekst] / E.G. Fedosenko, D.G. Gvazava // Vestnik APK Verhnevolzh'ja. - 2018. - № 3 (43). - S. 46-49.

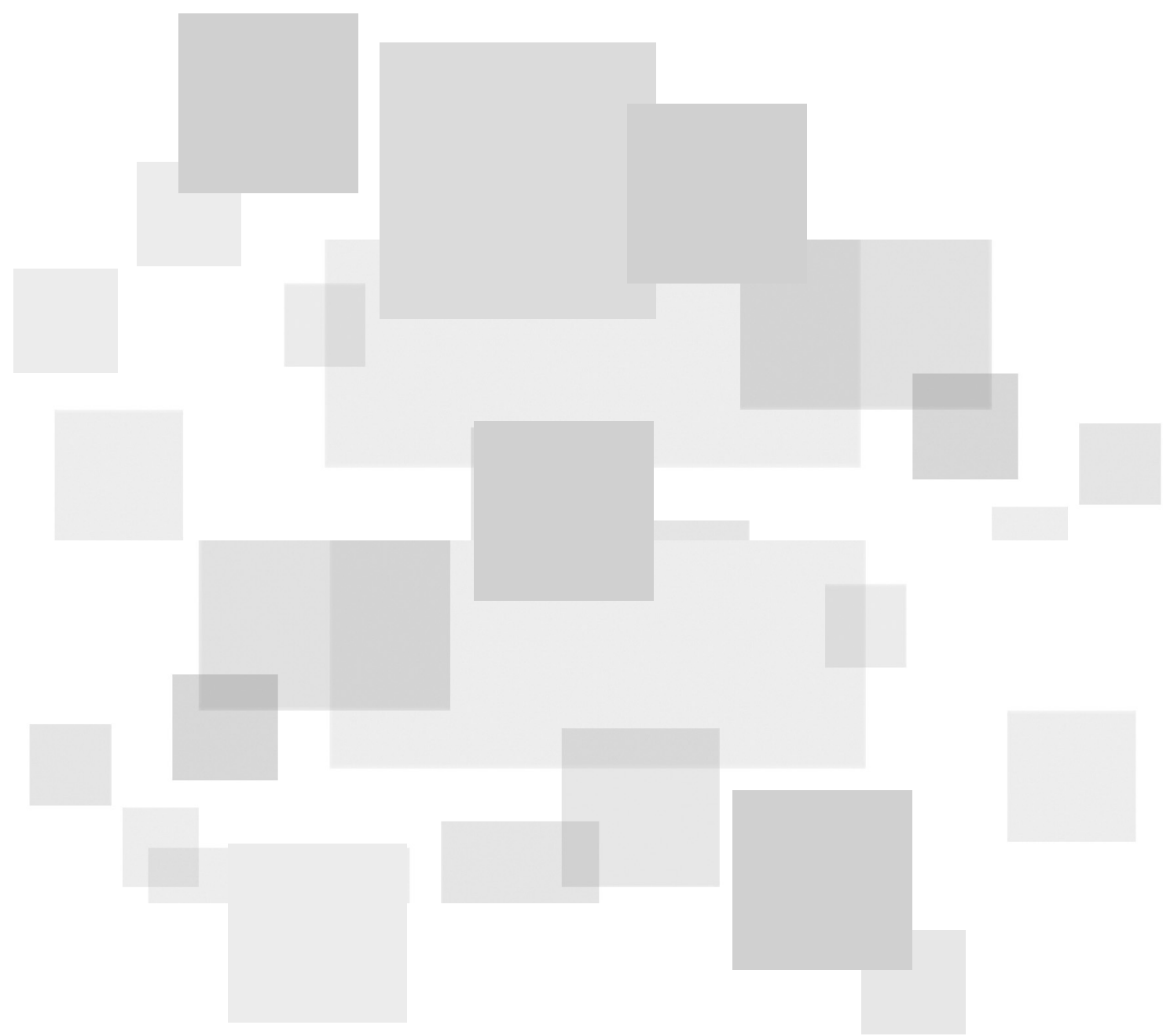

